\title{
LATE QUATERNARY CAVIOMORPH RODENTS (RODENTIA: HYSTRICOGNATHI) FROM CEARÁ STATE, NORTHEAST BRAZIL
}

\author{
Paulo Victor de Oliveira ${ }^{1}$, Ana Maria Ribeiro ${ }^{2}$, Leonardo Kerber ${ }^{2}$, Gisele Lessa ${ }^{3}$ \\ and Maria Somália Sales Viana ${ }^{4}$
}

\begin{abstract}
In this paper we report the first remains of caviomorph rodents from the karst of the Parque Nacional de Ubajara, Ceará State, northeastern Brazil, collected with precise stratigraphic and radiometric control. The material is derived from levels with thermoluminescence dating of about 8,000 years BP, corresponding to the early Holocene. In these levels, we found remains of Kerodon rupestris Wied, 1820, cf. Dasyprocta Illiger, 1811 and Thrichomys Trouessart, 1880. The data here reported contribute to the knowledge of Brazilian Quaternary rodents and show the potential of the studied area for fossils.
\end{abstract}

\section{INTRODUCTION}

Caviomorphs are South American hystricognath rodents that arrived on the continent probably during the Eocene (Wyss et al., 1993; Poux et al., 2006; Antoine et al., 2011). During the Cenozoic, the group achieved great ecological and morphological diversity and occupied several niches. The oldest records of this group in Brazil are from the Oligocene Tremembé Formation (Vucetich et al., 1993; Vucetich and Ribeiro, 2003) and the Miocene of Acre State (see Negri et al., 2010). Younger records are exclusively from the late Quaternary. However, these records are poorly studied. Recent studies from several Quaternary localities in South America have shown interesting results, with descriptions of new taxa and different paleobiogeographic patterns in comparison with the modern fauna (e.g., Cartelle and Lessa, 1989; Vucetich et al., 1997; Vucetich and Verzi, 2002; Ubilla et al., 2008; Hadler et al., 2008; Kerber et al., 2011a, b; Rodrigues et al., 2011). The cited papers demonstrate the need to use multiple approaches to understand the evolution of South American Quaternary rodents.

In northeastern Brazil several records of Quaternary mammals have been reported, mainly from karsts and tanques. But the small mammals are poorly studied in comparison with the large- and medium-bodied taxa and are often not recovered with associated stratigraphic or radiometric data. During July 2009, an expedition to the caves of the Parque Nacional de Ubajara, Ceará State, northeast Brazil, was made to collect fossil remains with precise stratigraphic and radiometric control. In this paper, we describe the remains of caviomorph rodents collected during this expedition.

\section{Material And Methods}

The remains are deposited in the paleovertebrate collection of the Museu Dom José. They comprise nine specimens, including isolated teeth and fragments of dentary and maxilla.

Dental nomenclature follows Quintana (1996) for Caviidae and Patterson and Wood (1982) for Echimyidae and Dasyproctidae. However, these nomenclatures do not reflect any opinion on the homologies of these structures. The anatomical nomenclature of the dentary of Cavioidea follows Pérez (2010). The comparative specimens are listed in appendix 1. Institutional abbreviations: MCPU-M, Coleção de Mastozoologia, Pontifícia Universidade Católica do Rio Grande do Sul, Uruguaiana, Rio Grande do Sul, Brazil; MDJ M, Coleção de Mastozoologia, Museu Dom José, Sobral, Ceará, Brazil; MLP, Colección de Mastozoología, Museo de La Plata, Argentina; MN, Coleção de Mastozoologia, Museu Nacional, Rio de Janeiro, Brazil.

\section{Location and Geological Setting}

The Parque Nacional de Ubajara, located in Ubajara Municipality (Fig. 1), in the Ibiapaba Cuesta region in northwestern Ceará (northeast Brazil), has a significant karst system. According to IBAMA (2002) the speleological province of the Ubajara region consists of nine limestone hills, in which fourteen caves are known to date. The limestone rock outcrops in the region correspond to the Neoproterozoic Frecheirinha Formation of the Ubajara Group of the Ubajara Graben (Quadros, 1996; CPRM, 2003). The Ubajara Group has an upper discordant

\footnotetext{
${ }^{1}$ Departamento de Geologia, Centro de Tecnologia e Geociências da Universidade Federal de Pernambuco, Av. Acadêmico Hélio Ramos, $s / n^{\circ}$, Cidade Universitária, 50740-530, Recife, PE, Brazil, victoroliveira.paleonto@gmail.com

${ }^{2}$ Seção de Paleontologia, Museu de Ciências Naturais, Fundação Zoobotânica do Rio Grande do Sul, Av. Salvador França, 1427, 90690-000, Porto Alegre, RS, Brazil, ana-ribeiro@fzb.rs.gov.br; leonardokerber@gmail.com

${ }^{3}$ Universidade Federal de Viçosa, Departamento de Biologia Animal, Campus Universitário, s/n ${ }^{\circ}$ Centro, 36570-000, Viçosa, MG, Brazil, gislessa@yahoo.com.br ${ }^{4}$ Laboratório de Paleontologia, Museu Dom José, Universidade Estadual Vale do Acaraú (LABOPALEO-MDJ/UVA), Av. Dom José, 878, 62010-190, Sobral, CE, Brazil, somalia_viana@hotmail.com
} 


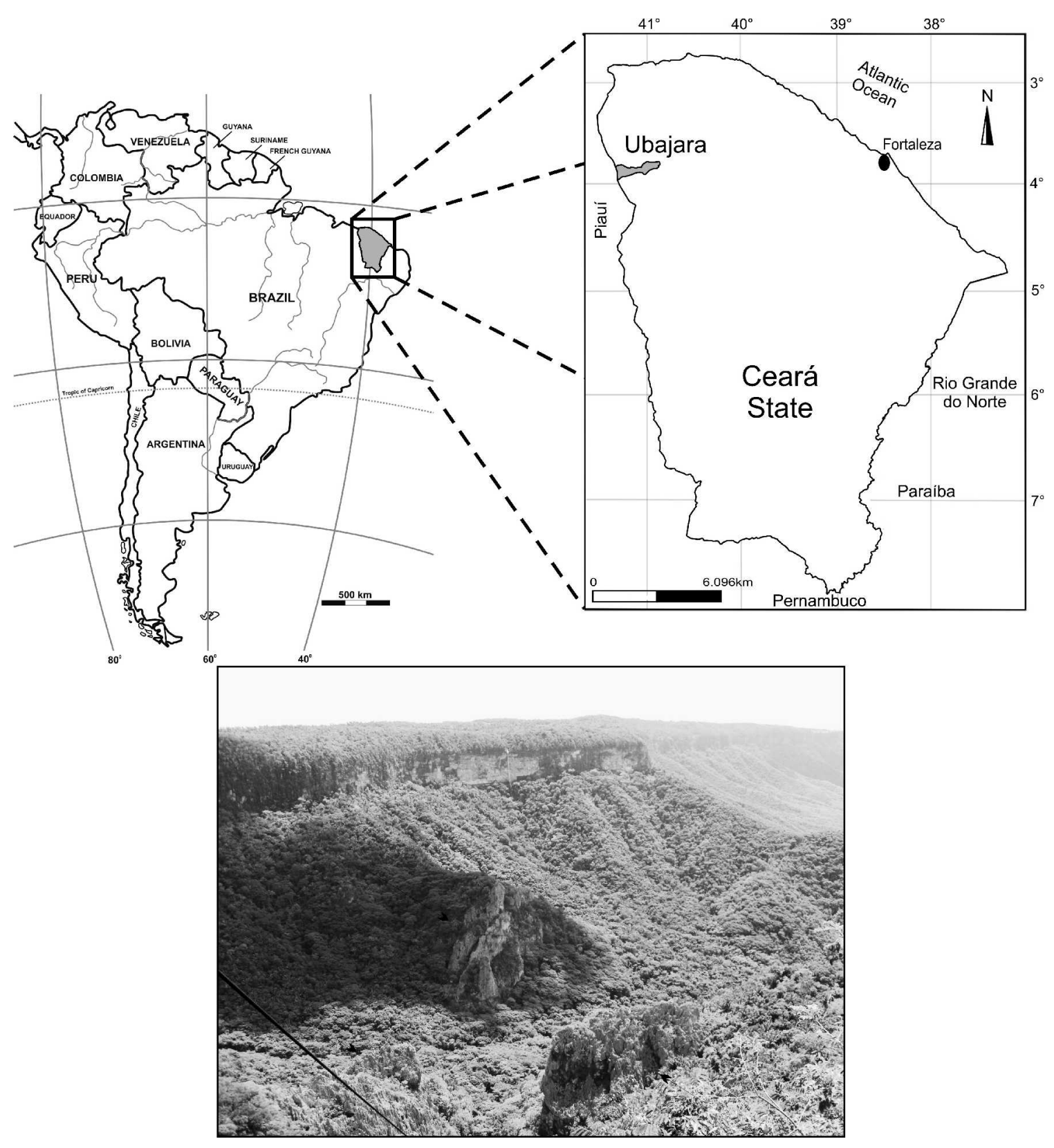

Figure 1. Location map of the Parque Nacional de Ubajara, Ceará (above) and the openings of the caves (below) indicated by arrows.

contact with the Silurian-Devonian Serra Grande Group of the Parnaíba Basin. Among the limestone hills in the studied area stands Pendurado Hill, with two caves, Urso Fóssil and Pendurado.

Previous published information about the Quaternary mammals from this area includes a bear skull and mandible assigned to Arctotherium brasiliense (Lund, 1840) described by Trajano and Ferrarezzi (1994). These remains were found in the Urso Fóssil cave $\left(03^{\circ} 49^{\prime} 58^{\prime \prime} \mathrm{S}, 40^{\circ} 53^{\prime} 34.4^{\prime \prime} \mathrm{W}\right)$. The material studied here was found in one room of this cave, the Sala da Entrada. In this room we made a stratigraphically controlled excavation, exposing three levels of sedimentary deposition. A geological section provided information about unconsolidated accumulations of sediments of both allochthonous and autochthonous origin, from top to bottom (Fig. 2):

Level 1: $0.15 \mathrm{~m}$ thick, is composed of clayey calcareous sediments, light yellowish in color, containing small allochthonous fragments $(0.5-1 \mathrm{~cm})$ of amorphous and angular limestone, as well as a great amount of recent seeds and excrement.

Level 2: $0.35 \mathrm{~m}$ thick, is composed of clayey sediment, light gray in color, containing allochthonous fragments of limestone (greater than $2 \mathrm{~cm}$ ), some small geodes and 


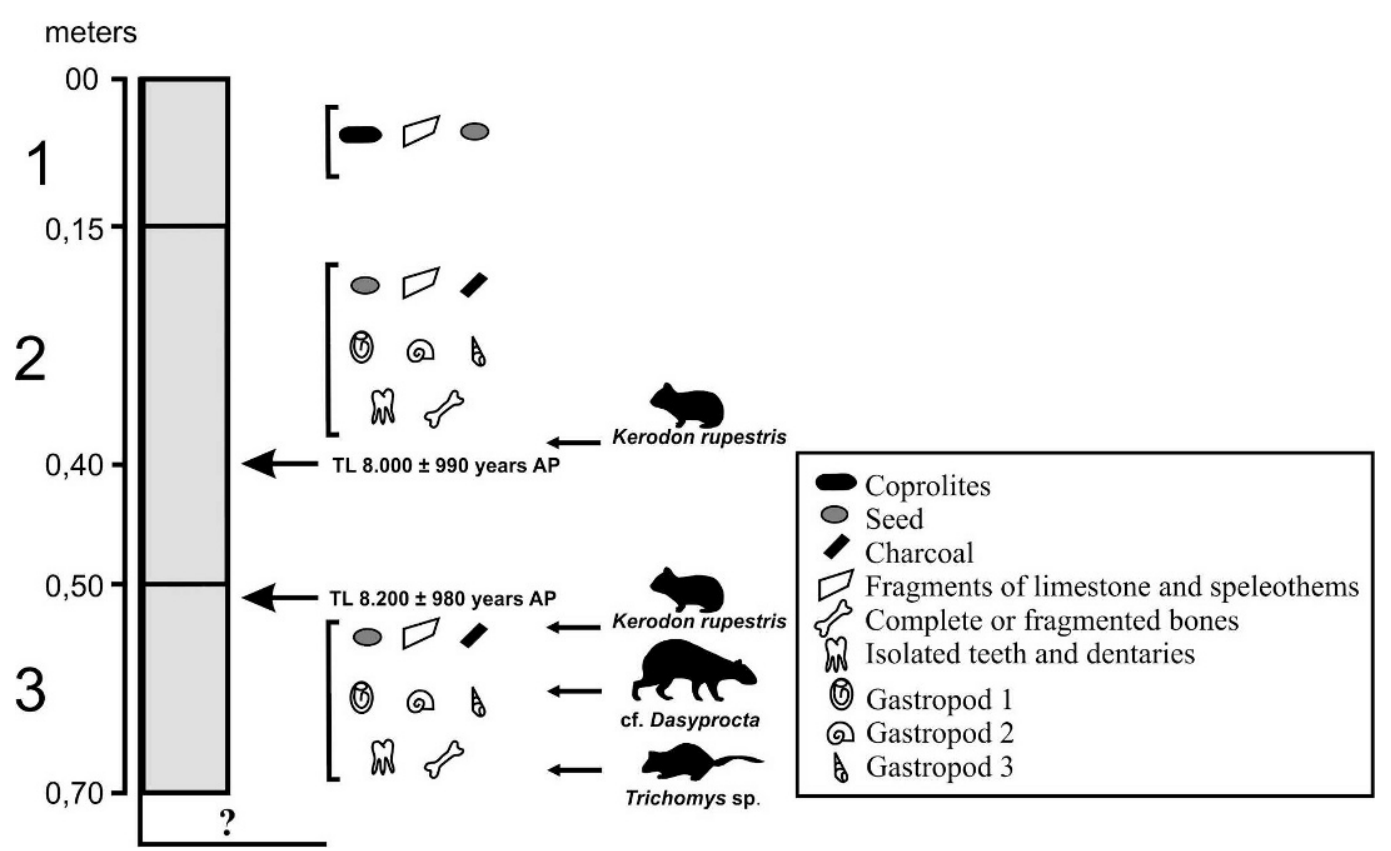

Figure 2. Stratigraphic profile of the sampled deposit in the Urso Fóssil cave, Salão dos Blocos Abatidos, Sala da Entrada, indicating where the fossils were collected.

fragments (approximately $10 \mathrm{~cm}$ ) of stalactites and others speleothems, showing at times, concentration of iron oxide. It contains, at the top, a high concentration of two types of seeds that are still undetermined; toward the bottom of the layer, some complete shells and numerous shell fragments have accumulated. There are some small droppings covered by powdered carbonate, but still unconsolidated. At about $20 \mathrm{~cm}$ from the top of this layer, we collected sediment samples for thermoluminescence dating in a PVC pipe and then, below, for recovery of palynomorphs. We also collected three species of gastropods and numerous bone fragments of Didelphimorphia, Xenarthra, and Rodentia.

Level 3: $0.20 \mathrm{~m}$ thick, is composed of clayey sediment containing smaller autochthonous fragments of limestone and very large and angular calcareous blocks. In this level, shells and several small bone fragments occur. As in layer 2, samples for thermoluminescence dating were collected, along with the remains of squamate reptiles and mammals of the Didelphimorphia, Xenarthra, Rodentia and Artio dactyla.

These fossil assemblages could have been accumulated by predators or scavengers or overflow of owl. A taphonomic study is currently underway.

\section{Systematic Paleontology}

Rodentia Bowdich, 1821

Hystricognathi Tullberg, 1899

Caviomorpha Patterson and Wood (in Wood, 1955)

Cavioidea Fischer de Waldheim, 1817

Genus Kerodon Cuvier, 1825
Kerodon rupestris Wied, 1820

(Fig. 3)

Material: MDJ M-845, fragment of right dentary with incomplete p4; MDJ M-846, fragment of left dentary; MDJ M-888, fragment of right dentary with p4; MDJ M-890, toothless and incomplete right dentary.

Geographic and stratigraphic provenance: Parque Nacional de Ubajara, Pendurado Hill, Urso Fóssil cave: Sala da Entrada, levels 2 and 3.

Description: The dentary has the anteriormost area of the horizontal crest (sensu Pérez, 2010) at the level of the mesial area of the $\mathrm{p} 4$, and the anteriormost area of the notch for the insertion of the tendon of the masseter medialis pars infraorbitalis muscle (sensu Woods and Howland, 1979; and Pérez, 2010) is located below the pr. I of the $\mathrm{m} 1$ alveolus. The symphysis is narrow and long. The mental foramen is positioned on the lateral side of the diastema. In medial view, the alveolus of the incisor extends posteriorly up to the level of the pr. II of p4 and pr. I of the $\mathrm{m} 1$ contact. The $\mathrm{p} 4$ is euhypsodont, and the anterior additional elongation is well developed, as a true prism. The anterior additional elongation and the prisms are transversally oriented, increasing in size distally. The prisms are united by a thin and very short isthmus. On the lingual surface of the tooth there are two poorly developed furrows, one on the pr. II and another on the additional elongation. The hypoflexid extends almost the entire width of the tooth. In the lingual ends of the labial flexids there is cement.

Discussion: Traditionally, Kerodon was considered a member of the Caviinae. However, recent studies have 


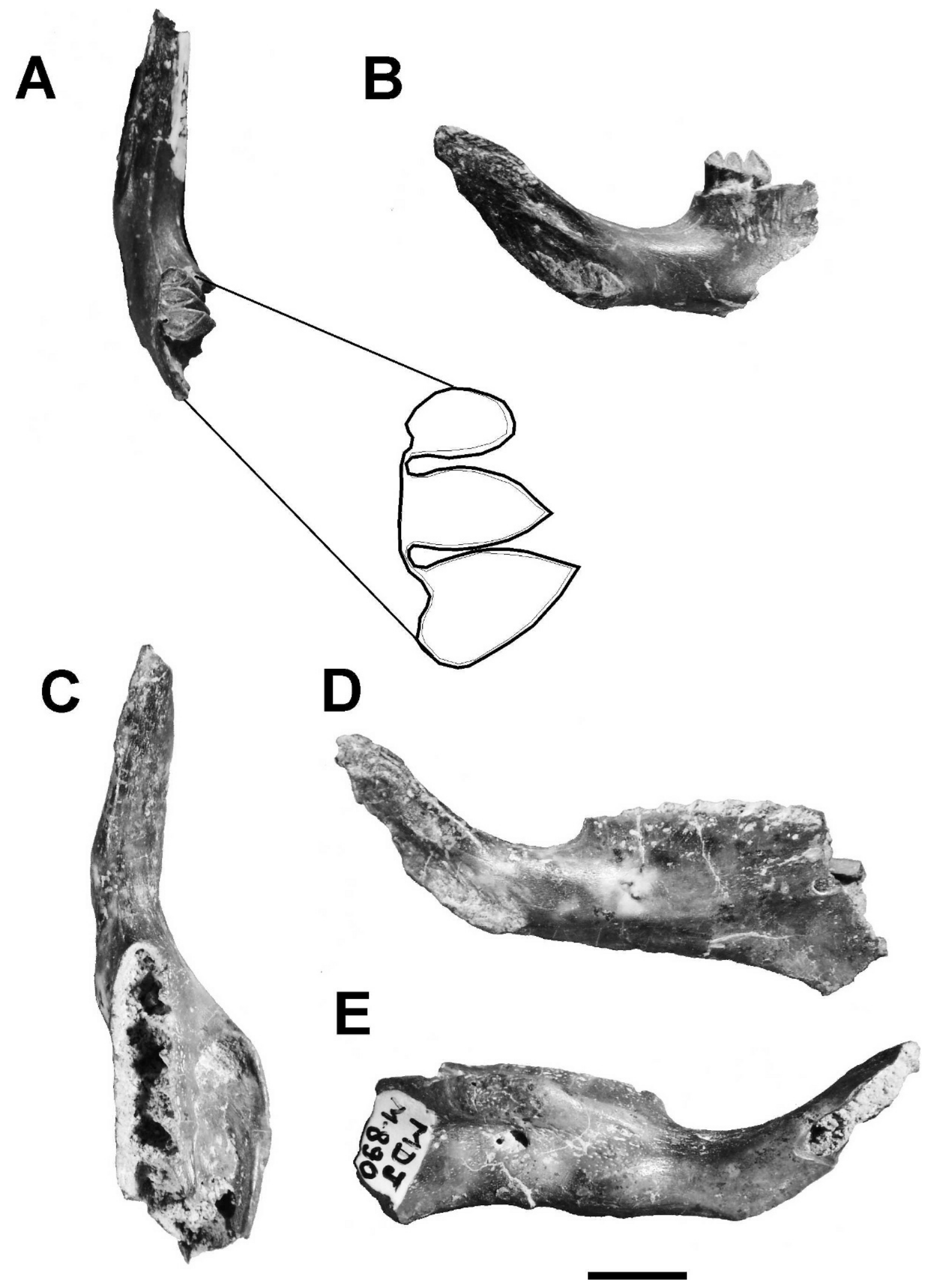

Figure 3. Right dentary of Kerodon rupestris from the early Holocene of Ceará. MDJ M-888 with p4 in detail, in occlusal (A) and medial (B) views. MDJ M-890 in occlusal (C), medial (D) and lateral (E) views. Scale bar: 5 mm. 


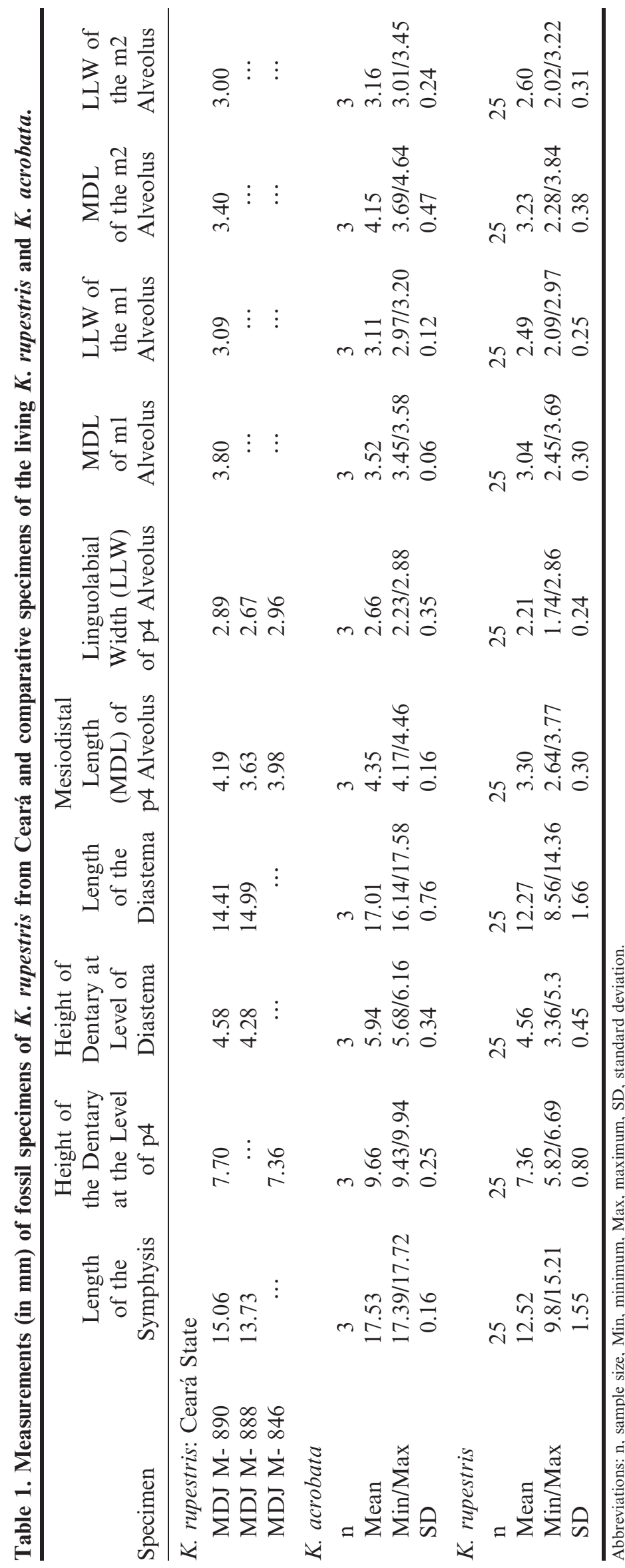

considered it more closely related to the Hydrochoeridae (see Rowe and Honeycutt, 2002). In the cladistic analysis of Pérez (2010), Kerodon is the sister group of Cardiomys Ameghino, 1885 (Caviidae: Cardiomyinae) plus the Hydrochoeridae.

The specimens here reported differ from the other Quaternary caviids, such as Galea Meyen, 1832, Microcavia Gervais \& Ameghino, 1880 and Cavia Pallas, 1766, in the presence of a longer and narrower symphysis and a triprismatic p4. Currently, the genus Kerodon has two extant species: $K$. acrobata Moojen, Locks \& Langguth, 1997 and K. rupestris, the latter being recorded in the Parque Nacional de Ubajara (Guedes et al., 2000). The fossil specimens share with both taxa the anterior area having a horizontal crest at the level of the p4, the anterior area of the notch for the insertion of the tendon of the masseter medialis pars infraorbitalis muscle located below the pr. I of the $\mathrm{m} 1$, and a triprismatic $\mathrm{p} 4$ with labial furrows. However, they are different from $K$. acrobata in the presence of the anterior area of the horizontal crest being less prominent anteriorly and in having a smaller symphysis, diastema, and height of the dentary (Table 1; Fig. 4).

Kerodon are often associated with rocky and dry environments from Caatinga and Cerrado (Oliveira and Bonvicino, 2006). The fossil record of this taxon is very scarce. The only records are from the late Pleistocene/ Holocene of northeast Brazil (Guérin et al., 1993; Lessa et al., 2008; Rodrigues et al., 2011). These records are within the modern range of $K$. rupestris. Lessa and Gonçalves (1999) reported specimens of $K$. rupestris from the late Pleistocene/Holocene of Bahia, these being larger than the Recent specimens. This fact was not observed in the specimens analyzed here.

Dasyproctidae Smith, 1842

cf. Dasyprocta Illiger, 1811

(Fig. 5)

Material: MDJ M-882 right $\mathrm{m} 1$ or $\mathrm{m} 2$; MDJ M-880 right $\mathrm{m} 1$ or $\mathrm{m} 2$.

Geographic and stratigraphic provenance: Parque Nacional de Ubajara, Pendurado Hill, Urso Fóssil cave: Sala da Entrada, level 3.

Description: The description is based on MDJ M-882, which is better preserved (Fig. 5A). The tooth has a subrectangular outline, and the distal enamel layer is more curved than the mesial. It is protohypsodont, and the degree of hypsodonty is similar to that seen in Dasyprocta and Myoprocta and distinct from the Quaternary dasyproctid Plesiaguti Vucetich \& Verzi, 2002, in which it is less hypsodont. It is pentalophodont, such as in the living dasyproctids (Dasyprocta and Myoprocta), and the lingual flexids are closed, forming fossetids. The lingual end of the hypoflexid is opposite the tip of the fourth flexid, but they are not confluent. The second and third flexids are connected by their labial ends, and the third lophid is interrupted. 

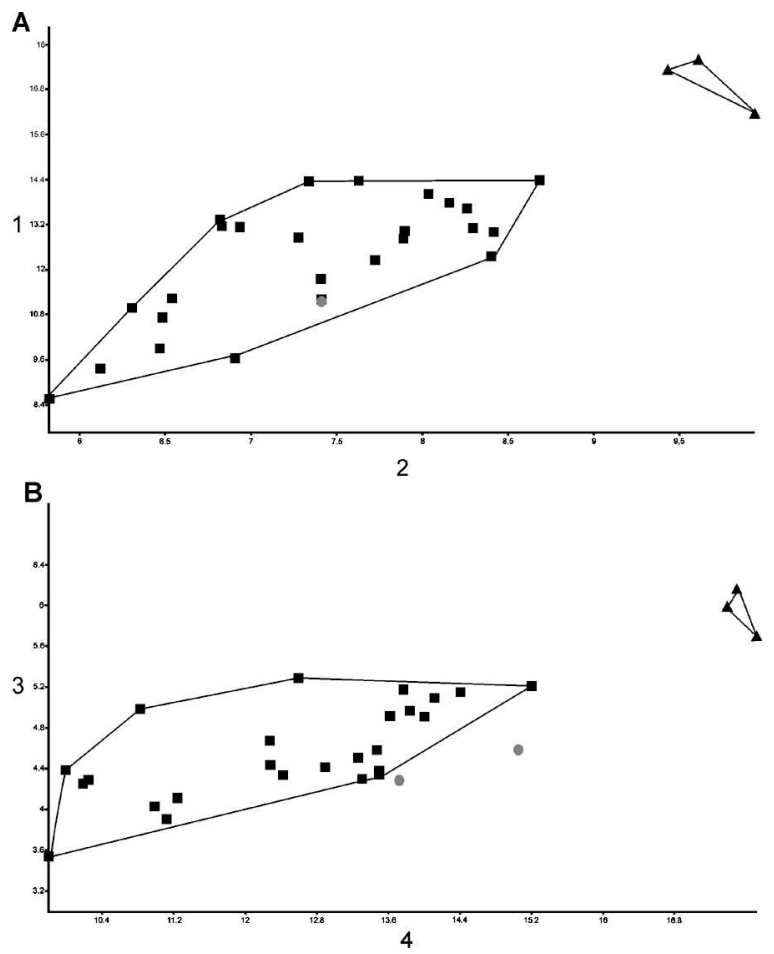

Figure 4. Bivariant diagrams of measurements of fossils of $K$. rupestris (gray circles), living $K$. rupestris (black square), and $K$. acrobata (black triangle). (A) Including the specimen MDJ M-890 and comparative specimens. (B) Including MDJ M-890, MDJ M- 888 and comparative specimens. 1. Length of the diastema; 2 . Height of the dentary at the level of $\mathbf{p}$; 3. Height of the dentary at the level of diastema; 4 . Length of the symphysis.
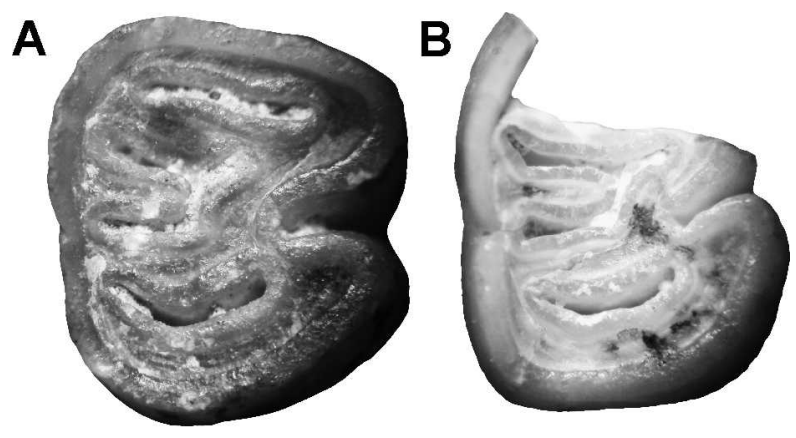

Figure 5. Right $\mathrm{m} 1$ or $\mathrm{m} 2$ in occlusal view of cf. Dasyprocta from the early Holocene of Ceará. (A) MDJ M-882 and (B) MDJ M-880. Scale bar: $3 \mathrm{~mm}$.

Measurements of MDJ M-882: Mesiodistal length $4.36 \mathrm{~mm}$; Linguolabial width $-3.94 \mathrm{~mm}$.

Discussion: The morphology of the teeth of Dasyprocta and Myoprocta are similar, but in Dasyprocta they are larger. The specimens described here are slightly larger than Myoprocta specimens used for comparison, and they are within the variation of $D$. prymnolopha (Table 2).

The living Dasyprocta include several species that inhabit almost all lowland tropical forest areas in the South and Central Americas. In Brazil, the review of IackXimenes (1999) recognized the following species: $D$. aurea Cope, 1889, D. azarae Lichtenstein, 1823, D. catrinae (Thomas, 1917), D. fuliginosa Wagler, 1832, D. croconota Wagler, 1831, D. leporina (Linneus, 1758), D. nigriclunis Osgood, 1916, D. prymnolopha Wagler, 1841 and D. aguti

Table 2. Measurements of comparative specimens of the living dasyproctids: Dasyprocta azarae, D. prymnolopha and Myoprocta exilis.

\begin{tabular}{lcccc}
\hline Specimen & $\begin{array}{c}\text { Mesiodistal Length } \\
\text { of the } \mathrm{m} 1\end{array}$ & $\begin{array}{c}\text { Linguolabial Width } \\
\text { of the } \mathrm{m} 1\end{array}$ & $\begin{array}{c}\text { Mesiodistal Length of } \\
\text { the } \mathrm{m} 2\end{array}$ & $\begin{array}{c}\text { Linguolabial Width } \\
\text { of the } \mathrm{m} 2\end{array}$ \\
\hline $\begin{array}{l}\text { D. azarae } \\
\mathrm{n}\end{array}$ & 11 & 11 & 11 & 11 \\
Mean & 4.76 & 4.22 & 4.94 & 4.28 \\
Min/Max & $4.03 / 5.05$ & $3.19 / 5.04$ & $4.57 / 5.61$ & 3.58 \\
SD & 0.30 & 0.47 & 0.35 & 0.51 \\
D. prymnolopha & & & & 10 \\
$\mathrm{n}$ & 11 & 11 & 10 & 3.65 \\
Mean & 4.12 & 3.72 & 4.26 & $3.33 / 3.98$ \\
Min/Max & $3.83 / 4.47$ & $3.25 / 4.02$ & $4.06 / 4.49$ & 0.23 \\
SD & 0.20 & 0.25 & 0.16 & 11 \\
M. exilis & & & 11 & 3.4 \\
$\mathrm{n}$ & 11 & 11 & 3.67 & $2.84 / 3.81$ \\
Mean & 3.23 & 3.24 & $3.37 / 4.07$ & 0.27 \\
Min/Max & $3.0 / 3.42$ & $3.0 / 3.53$ & 0.23 & \\
SD & 0.14 & 0.21 & & \\
\hline
\end{tabular}

Abbreviations: n, sample size, Min, minimum, Max, maximum, SD, standard deviation. 


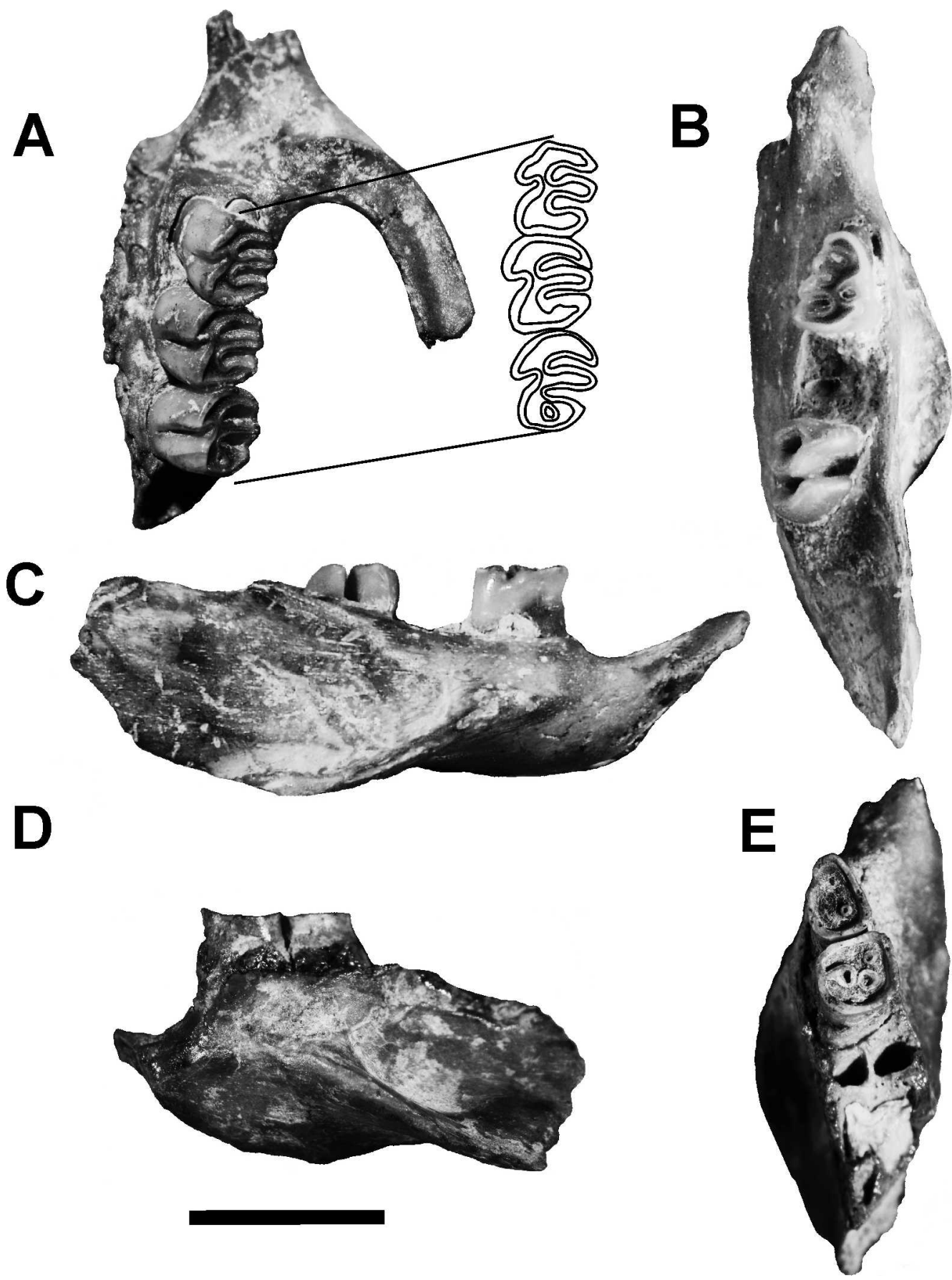

Figure 6. Thrichomys sp. from the early Holocene of Ceará. (A) Fragment of a left maxilla, with the DP4, M1 and M2 (MDJ M-891) in palatal view, with detail of the cheek teeth in occlusal view. (B-C) Right dentary with dp4 and m2 (MDJ M-893) in occlusal (B) and lateral (C) views. (D-E) Left dentary with dp4 and m1 (MDJ M-892), in lateral (D) and occlusal (E) views. Scale bar: 5 mm.

(Linnaeus, 1766). However, according to the list of valid species in Woods and Kilpatrick (2005), D. aurea, D. catrinae and $D$. aguti are synonyms of $D$. azarae, $D$. nigriclunis is synonym of $D$. prymnolopha, and $D$. croconota is a subspecies of D. leporina. Dasyprocta is distributed in almost all regions of Brazil, while Myoprocta is restricted to the Amazonian forest. According to Guedes et al.
(2000), the only living dasyproctid in the Parque Nacional de Ubajara is $D$. prymnolopha.

The living species of Dasyprocta are terrestrial and are often associated with water bodies, feeding mainly on fruits, seeds, roots, and leaves (Oliveira and Bonvicino, 2006). The fossil record of this genus is very scarce. According to Vucetich and Verzi (1994), the living 
Table 3. Upper cheek teeth measurements of the fossil specimen of Thrichomys sp. from Ceará and comparative specimens of the living $T$. aperoides, $T$. inermis and $T$. pachyurus.

\begin{tabular}{|c|c|c|c|c|c|c|}
\hline Specimen & $\begin{array}{l}\text { Mesiodistal Length } \\
\text { (MDL) of the DP4 }\end{array}$ & $\begin{array}{l}\text { Linguolabial Width } \\
\text { (LLW) of the DP4 }\end{array}$ & $\begin{array}{l}\text { MDL of } \\
\text { the M1 }\end{array}$ & $\begin{array}{l}\text { LLW of } \\
\text { the M1 }\end{array}$ & $\begin{array}{l}\text { MDL of } \\
\text { the M2 }\end{array}$ & $\begin{array}{l}\text { LLW of } \\
\text { the M2 }\end{array}$ \\
\hline MDJ M-891 & 2.49 & 2.05 & 2.72 & 2.41 & 2.46 & 2.40 \\
\hline \multicolumn{7}{|l|}{ T. aperoides } \\
\hline $\mathrm{N}$ & 16 & 16 & 16 & 16 & 16 & 16 \\
\hline Mean & 2.17 & 2.00 & 2.31 & 2.36 & 2.35 & 2.49 \\
\hline Min/Max & $1.87 / 2.4$ & $1.63 / 2.19$ & $2.02 / 2.65$ & $1.36 / 2.86$ & $2.01 / 2.69$ & $1.99 / 2.95$ \\
\hline $\mathrm{SD}$ & 0.13 & 0.14 & 0.16 & 0.37 & 0.19 & 0.30 \\
\hline \multicolumn{7}{|l|}{ T. inermis } \\
\hline $\mathrm{N}$ & 16 & 16 & 16 & 16 & 16 & 16 \\
\hline Mean & 2.06 & 1.96 & 2.16 & 2.23 & 2.28 & 2.32 \\
\hline Min/Max & $1.8 / 2.32$ & $1.8 / 2.39$ & $2.01 / 2.43$ & $2.0 / 2.49$ & $2.06 / 2.55$ & $1.93 / 2.8$ \\
\hline $\mathrm{SD}$ & 0.12 & 0.14 & 0.11 & 0.16 & 0.14 & 0.28 \\
\hline \multicolumn{7}{|l|}{ T. pachyurus } \\
\hline $\mathrm{N}$ & 11 & 11 & 11 & 11 & 11 & 11 \\
\hline Mean & 2.28 & 2.23 & 2.39 & 2.61 & 2.49 & 2.63 \\
\hline Min/Max & $2.07 / 2.57$ & $2.06 / 2.56$ & $2.12 / 2.75$ & $2.41 / 3.11$ & $2.02 / 2.91$ & $2.21 / 3.33$ \\
\hline $\mathrm{SD}$ & 0.13 & 0.13 & 0.18 & 0.24 & 0.23 & 0.37 \\
\hline
\end{tabular}

Abbreviations: $\mathrm{n}$, sample size, Min, minimum, Max, maximum, SD, standard deviation.

dasyproctids are not related to the taxa from the Tertiary of Argentina. These authors suggest that they have an intertropical/tropical history. Quaternary records for Dasyprocta are reported from the Pará, Minas Gerais,
Espírito Santo, Bahia, Goiás, and Mato Grosso do Sul states of Brazil (Paula Couto, 1971; 1978; Salles et al., 1999; 2006; Toledo et al., 1999; Lessa et al., 2008). There is no definitive fossil record of Myoprocta.

Table 4. Measurements of lower cheek teeth and dentary of fossil specimens of Thrichomys sp. from Ceará and comparative specimens of the living $T$. aperoides, $T$. inermis and $T$. pachyurus.

\begin{tabular}{|c|c|c|c|c|c|c|c|}
\hline Specimen & $\begin{array}{l}\text { Mesiodistal } \\
\text { Length (MDL) } \\
\text { of the dp4 }\end{array}$ & $\begin{array}{l}\text { Linguolabial } \\
\text { Width (LLW) } \\
\text { of the dp4 }\end{array}$ & $\begin{array}{l}\text { MDL of } \\
\text { the } \mathrm{m} 1\end{array}$ & $\begin{array}{l}\text { LLW of } \\
\text { the } \mathrm{m} 1\end{array}$ & $\begin{array}{l}\text { MDL of } \\
\text { the } m 2\end{array}$ & $\begin{array}{l}\text { LLW of } \\
\text { the } \mathrm{m} 2\end{array}$ & $\begin{array}{l}\text { Height of the } \\
\text { Dentary at the } \\
\text { Level of } d p 4\end{array}$ \\
\hline MDJ M -892 & 2.32 & 1.62 & 2.20 & 2.28 & ..• & ... & $\ldots$ \\
\hline MDJ M- 893 & 2.52 & 1.75 & ... & ... & 2.51 & 1.72 & 4.86 \\
\hline \multicolumn{8}{|l|}{ T. aperoides } \\
\hline $\mathrm{N}$ & 16 & 16 & 16 & 16 & 16 & 16 & 16 \\
\hline Mean & 2.51 & 1.76 & 2.41 & 2.20 & 2.58 & 2.24 & 6.34 \\
\hline Min/Max & $2.09 / 3.02$ & $1.63 / 2.01$ & $1.88 / 2.69$ & $1.89 / 2.48$ & $2.17 / 3.03$ & $1.45 / 2.69$ & $5.45 / 7.48$ \\
\hline $\mathrm{SD}$ & 0.21 & 0.10 & 0.22 & 0.16 & 0.22 & 0.21 & 0.60 \\
\hline \multicolumn{8}{|l|}{ T. inermis } \\
\hline $\mathrm{N}$ & 16 & 16 & 16 & 16 & 16 & 16 & 16 \\
\hline Mean & 2.22 & 1.56 & 2.14 & 2.11 & 2.33 & 2.09 & 6.43 \\
\hline Min/Max & $1.85 / 2.45$ & $1.35 / 1.76$ & $2.01 / 2.32$ & $1.73 / 1.93$ & $2.07 / 2.58$ & $1.88 / 2.42$ & $5.11 / 7.12$ \\
\hline $\mathrm{SD}$ & 0.15 & 0.11 & 0.10 & 0.25 & 0.14 & 0.14 & 0.54 \\
\hline \multicolumn{8}{|l|}{ T. pachyurus } \\
\hline $\mathrm{N}$ & 11 & 11 & 11 & 11 & 11 & 11 & 11 \\
\hline Mean & 2.58 & 2.06 & 2.45 & 2.50 & 2.57 & 2.60 & 7.33 \\
\hline Min/Max & $2.4 / 2.8$ & $2.0 / 2.23$ & $2.25 / 2.81$ & $2.37 / 2.71$ & $2.33 / 2.97$ & $2.37 / 3.08$ & $6.20 / 8.67$ \\
\hline $\mathrm{SD}$ & 0.10 & 0.07 & 0.16 & 0.09 & 0.18 & 0.22 & 0.79 \\
\hline
\end{tabular}


Octodontoidea Simpson, 1945

Echimyidae Gray, 1825

Genus Thrichomys Trouessart, 1880

Thrichomys sp.

(Fig. 6)

Material: MDJ M-891, fragment of left maxilla with DP4, M1 and M2; MDJ M-892, fragmented dentary with dp4 and m1; MDJ M-893, fragmented dentary with dp4 and $\mathrm{m} 2$.

Geographic and stratigraphic provenance: Parque Nacional de Ubajara, Pendurado Hill, Urso Fóssil cave, Salão dos Blocos Abatidos; Sala da Entrada, level 3.

Description: In MDJ M-891, DP4-M2 are similar. Both are trilophodont; however, the M2 has a small fosset in the posteroloph. This fosset is present in some comparative specimens of $T$. apereoides (e.g., MN 63198), but it is reduced (e.g., MN 63200), or absent (e.g., MN 63199) in older individuals. The protocone is slightly distally oriented, and the linguodistal area of the teeth forms a slightly acute angle, more evident in the M1. The lingual area of the anteroloph, the paracone, and the metacone are transversally oriented. All the labial flexi are open, transversally oriented, and extend up to the middle of the occlusal surface, not surpassing the tip of the hypoflexus. The hypoflexus is oblique, slightly mesially oriented, and less developed than the labial flexi, and its labial end is opposite the first labial flexus.

The dp4 (MDJ M-893) is tetralophodont, with a welldeveloped metalophid. This character differs from other echimyids traditionally grouped in the "Eumysopinae" (see Verzi et al., 1995), such as Euryzygomatomys Goeldi, 1901 and Clyomys Thomas, 1916, in which the p4 is trilophodont, with an absent or much reduced metalophid (Verzi et al., 1995; Hadler et al., 2008). The $\mathrm{m} 2$ of this specimen is little worn, with the lingual flexids still open and the posterolophid isolated from the anterior elements. The $\mathrm{m} 3$ is not erupted. MDJ M-892 is an old individual with the dp4 deeply worn and the m1 with all flexids transformed into fossettids (hypofossettid and two lingual fossettids).

In the dentary (MDJ M-893, MDJ M-892), the masseteric crest is tilted, and its anterior area is at the level of the dp4. Considering the comparative specimens, the fossils share with $T$. aperoides the masseteric crest being less developed and the masseteric fossa being less deep than in $T$. pachyurus and $T$. inermis.

Discussion: The subfamily "Eumysopinae" comprises the echimyids with a simplified occlusal pattern, with trilophodont molars. Traditionally, the Eumysopinae encompasses the living taxa Thrichomys, Carterodon Waterhouse, 1848, Clyomys, Euryzygomatomys, Hoplomys Allen, 1908, Lonchothrix Thomas, 1920, Mesomys Wagner, 1845, Proechimys Allen, 1899, and Trinomys Thomas, 1921 and diverse fossil taxa, mainly from the Tertiary of Argentina. Verzi et al. (1995) considered Eumysopinae as a natural group. However, in morphological and molecular cladistic analyses, this subfamily does not form a monophyletic group (e.g., Lara et al., 1996; Carvalho and Salles, 2004; Emmons, 2005; Galewski et al., 2005).

Currently, the genus Thrichomys has a complex taxonomic history. Some authors have considered it a single valid species, $T$. apereoides (Lund, 1839), with several subspecies (see Reis and Pessôa, 2004), while others considered it to include, at the very least, four species: $T$. apereoides, T. pachyurus (Wagner, 1841), T. inermis (Pictet, 1841) and T. laurentius Thomas, 1904 (see Oliveira and Bonvicino, 2006). Pessôa et al. (2004), on the basis of chromosomal and morphometric analyses recognized at least two well-defined species: $T$. apereoides and $T$. pachyurus. Recently, Neves and Pessôa (2011) described some cranial traits to distinguish $T$. pachyurus, T. inermis, and $T$. laurentius, but unfortunately, these characters are not preserved in the fossil specimens. In size, the fossil specimens do not differ significantly from the comparative specimens (Tables 3 and 4). Thus, the remains here reported are assigned to Thrichomys sp. due to the fragmentary condition of the material. In recent times, $T$. apereoides has been reported in the Parque Nacional de Ubajara (Guedes et al., 2000).

Thrichomys is a scansorial rodent and has been found in several areas of Brazil, from open areas up to the forests of Cerrado, Caatinga, and Pantanal. They are herbivores and feed on leaves and fruits (Bonvicino et al., 2008). In McKenna and Bell (1997), the stratigraphic distribution of Thrichomys is from the late Miocene to recent. However, the Miocene fossil record of this taxon is questionable (see Verzi et al., 1995). The confident fossil record of Thrichomys is very scarce, represented by a few Quaternary records in the Mato Grosso do Sul, Goiás, Minas Gerais, Pernambuco, and Piauí states of Brazil (Paula Couto, 1971; Guérin et al., 1993; Salles et al., 1999; 2006; Rodrigues et al., 2011), and now in Ceará State.

\section{FinAl Remarks}

Previous records of Quaternary rodents from northeast Brazil were exclusively from Bahia, Sergipe, Rio Grande do Norte, Pernambuco, and Piauí states (Oliveira et al., 1985; Guérin et al., 1993; Lessa et al., 2008; Dantas, 2009; Rodrigues et al., 2011), and now we are reporting a new assemblage for Ceará State. Unfortunately, some materials are very fragmented or there is a complex taxonomic situation in the living forms. Thus, it is not possible to assign a definite species name, such as in Thrichomys and cf. Dasyprocta.

The data reported here contribute to the knowledge of the Brazilian Quaternary rodents and shows the fossil potential of the studied area. Another Quaternary rodent found in Ubajara is the erethizontid Coendou prehensilis (Linnaeus, 1758) from the Urso Fóssil cave, but its stratigraphic provenance is not known exactly (Oliveira, 2010).

The material here reported is derived from levels with an age of about 8,000 years BP, corresponding to the early 
Holocene. Like the tayassuids, marsupials, and xenarthrans from these levels (Oliveira, 2010), the caviomorphs do not indicate any faunistic turnover during the Holocene in comparison with the living fauna.

The climates of the late Pleistocene and early Holocene in the northeast region were different from the present, with more humid and colder conditions, and there was a gradual increase in drier conditions throughout the Holocene (see de Oliveira et al., 2005 and references therein). The paleoecological indications of the taxa reported here are in accordance with the mosaic composition of the current environments of the Ubajara region, with humid forest at higher altitudes and open and dryer areas on the plains.

Mammalian faunas of the Holocene, with precise stratigraphic control, have been poorly studied from a paleontological point of view in Brazil. Recent studies have revealed interesting facts in other regions, showing recent extinctions, such as the case of southern Brazil. In this region, Hadler et al. (2008) reported the presence of some rodents distinct from the recent fauna, including a new species, Clyomys riograndensis. Recently, Rodrigues et al. (2011) reported the presence of a new Holocene vertebrate assemblage from Pernambuco State. In that work, the authors recognized, for the first time in the Quaternary of northeast Brazil, the presence of the rodent Phyllomys, which indicates the presence of more humid conditions in this area during some periods of the Holocene. To analyze these aspects in the karst of Ubajara, new fieldwork should be conducted to collect more material.

\section{ACKNOWLEDGEMENTS}

We thank: Conselho Nacional de Conselho Nacional de Pesquisa e Tecnologia ( $\mathrm{CNPq}$ ) for financial support to P.V.O. and L.K. in form of a doctoral fellowship in Programa de Pós-Graduação em Geociências of the Universidade Federal de Pernambuco (UFPE) and Programa de Pós-Graduação em Geociências of the Universidade Federal do Rio Grande do Sul (UFRGS), respectively; CNPq for financial support (Universal/ $n^{\circ}$ 473952/2008-4); Fundação Cearense de Apoio à Pesquisa e ao Desenvolvimento Científico e Tecnológico (BPI 0341-1.07/08) and Instituto de Apoio à Pesquisa e ao Desenvolvimento da Universidade Estaclual vale do Acaraú for financial support; Museu Dom José for the loan of the specimens; the institutions Departamento de Geologia da UFPE, Laboratório de Paleontologia da Universidade Estadual Vale do Acaraú and Fundação Zoobotânica do Rio Grande do Sul for the infrastructure provided; J.A. Oliveira, and S. Franco (Coleção de Mastozoologia, Museu Nacional, Brazil) and D. Verzi and I. Olivares (Colección de Mastozoología, Museo de La Plata, Argentina) for access to collections under their care; and three reviewers for their useful comments.

\section{REFERENCES}

Antoine, P.-O., Marivaux, L., Croft, D.A., Billet, G., Ganerød, M., Jaramillo, C., Martin, T., Orliac, M.J., Tejeda, J., Altamirano, A.J., Duranthon, F., Fanjat, G., Rouse, S., and Gismondi, R.S., 2011, Middle Eocene rodents from Peruvian Amazonia reveal the pattern and timing of caviomorph origin and biogeography: Proceedings of the Royal Society B, Biological Sciences, published online. doi:10.1098/rspb.2011.1732.

Bonvicino, C.R., Oliveira, J.A. de, and D'Andrea, P.S., 2008, Guia de Roedores do Brasil, com chaves para gêneros baseadas em caracteres externos, Rio de Janeiro, Centro Pan-Americano de Febre Aftosa OPAS/OMS, $120 \mathrm{p}$.

Cartelle, C.G., and Lessa, G., 1989, Presença de Myocastor coypus (Molina, 1782), Rodentia, Myocastoridae, do Pleistoceno FinalHoloceno, no centro-oeste da Bahia, in Anais, Congresso Brasileiro de Paleontologia, $11^{\text {th }}$, Curitiba, p. 583-591.

Carvalho, G.A.S., and Salles, L.O., 2004, Relationships among extant and fossil echimyids (Rodentia: Hystricognathi): Zoological Journal of the Linnean Society, v. 142, p. 445-477. doi:10.1111/j.1096-3642.2004. 00150.x.

CPRM (Serviço Geológico do Brasil), 2003, Atlas Digital de Geologia e Recursos Minerais do Ceará, Brasília, Ministério das Minas e Energia, CD-ROM.

Dantas, M.A.T., 2009, Primeiro registro de fósseis de mamíferos pleistocênicos em caverna de Sergipe, Brasil: Revista Brasileira de Paleontologia, v. 12, no. 2, p. 161-164. doi:10.4072/rbp.2009.2.06.

De Oliveira, P.E., Behling, H., Ledru, M.P., Barberi, M., Bush, M., Salgado-Labouriau, M.L., Garcia, M.J., Medeanic, S., Barth, O.M., de Barros, M.A., and Scheel-Ybert, R., 2005, Paleovegetação e paleoclimas do Quaternário do Brasil, in Souza, C.R.G., Suguio, K., Oliveira, A.M.S., and de Oliveira, P.E., eds., Quaternário do Brasil, São Paulo, Holos Editora, 2005, p. 52-74.

Emmons, L.H., 2005, A revision of the genera of arboreal Echimyidae (Rodentia: Echimyidae: Echimyinae), with description of two new genera, in Lacey, E.A., and Meyes, P., eds., Mammalian Diversification, From Chromosomes to Phylogeography (A celebration of the Career of James L. Patton), University of California Press, PUblications in Zoology, v. 133, p. 247-309.

Galewski, T., Mauffrey, J.-F., Leite, Y.L.R., Patton, J.L., and Douzery, E.J.P., 2005, Ecomorphological diversification among South American spiny rats (Rodentia; Echimyidae): a phylogenetic and chronological approach: Molecular Phylogenetics and Evolution, v. 34, p. 601-615. doi:10.1016/j.ympev.2004.11.015.

Guedes, P.G., Silva, S.S.P., Camardella, A.R., Abreu, M.F.G., BorgesNojosa, D.M., Silva, J.A.G., and Silva, A.A., 2000, Diversidade de mamíferos do Parque Nacional de Ubajara (Ceará, Brasil): Mastozoología Neotropical, v. 7, no. 2, p. 95-100.

Guérin, C., Curvello, M.A., Faure, M., Hungueney, M., and MourerChauvire, C., 1993, La faune pléistocène du Piauí (Nordeste du Brésil): implications paléoécologiques et biochronologiques: Quaternaria Nova, v. 3, p. 303-341.

Hadler, P., Verzi, D.H., Vucetich, M.G., Ferigolo, J., and Ribeiro, A.M., 2008, Caviomorphs (Mammalia, Rodentia) from the Holocene of Rio Grande do Sul State, Brazil: systematics and paleonviromental context: Revista Brasileira de Paleontologia, v. 11, no. 2, p. 97-116. doi:10.4072/rbp.2008.2.03

Iack-Ximenes, G.E., 1999, Sistemática da família Dasyproctidae Bonaparte, 1838 (Rodentia, Hystricognathi) no Brasil [Master thesis]. São Paulo, Universidade de São Paulo, 429 p.

IBAMA (Instituto Brasileiro do Meio Ambiente e dos Recursos Renováveis), 2002, Parque Nacional de Ubajara: Plano de Manejo: Brasília, Ministério do Meio Ambiente, CD-ROM.

Kerber, L., Lopes, R.P., Vucetich, M.G., Ribeiro, A.M., and Pereira, J., 2011a, Chinchillidae and Dolichotinae rodents (Rodentia, Hystricognathi, Caviomorpha) from the late Pleistocene of southern Brazil: Revista Brasileira de Paleontologia, v. 14, no. 3, p. 229-238. doi: 10.4072/rbp.2011.3.03.

Kerber, L., Ribeiro, A.M., and Oliveira, É.V., 2011b, The first record of Galea Meyen, 1832 (Rodentia, Hystricognathi, Caviidae) in the late Pleistocene of southern Brazil and its paleobiogeographic implications: Alcheringa, v. 35, no. 3, p. 445-457. doi:10.1080/03115518. 2011.533985. 
Lara, M.C., Patton, J.P., and Silva, M.N.F., 1996, The simultaneous diversification of South American echimyid rodents (Hystricognathi) based on complete cytochrome b sequences: Molecular Phylogenetics and Evolution, v. 5, no. 2, p. 403-413. doi:10.1006/mpev.1996.0035.

Lessa, G., Cartelle, C., and Manduca, E.G., 2008, Reevaluation of rodent assemblages from Pleistocene/Holocene of Bahia, Brazil: morphologic and environmental considerations, in Libro de Resúmenes, Congreso Latino-Americano de Paleontología de Vertebrados, $3^{\text {rd }}$, Neuquén, $137 \mathrm{p}$.

Lessa, G., and Gonçalves, P.R., 1999, Estudo comparativo de crânios de Kerodon rupestre (Mammalia, Rodentia) holo-pleistocênicos do nordeste brasileiro: Ameghiniana, v. 36, no. 1, 104 p.

McKenna, M.C., and Bell, S.K., 1997, Classification of Mammals above the Species Level, New York, Columbia University Press, 631 p.

Negri, F.R., Bocquetin-Villanueva, J., Ferigolo, J., and Antoine, P.-O., 2010, A review of Tertiary mammal faunas and birds from western Amazonia, in Hoorn, C., and Wesselingh, F.P., eds., Amazonia, Landscape and Species Evolution, A Look into the Past, Chichester, UK, Blackwell Publishing, p. 245-258. doi:10.1002/9781444306408.ch15.

Neves, A.C.S.A., and Pessôa, L.M., 2011, Morphological distinction of the species Thrichomys (Rodentia: Echimyidae) through ontogeny of cranial and dental characters: Zootaxa, no. 2804, p. 15-24.

Oliveira, J.A., and Bonvicino, C., 2006, Ordem Rodentia, in Reis, N.R., Peracchi, A.L., Pedro, W.A., and Lima, I.P., eds., Mamíferos do Brasil, Londrina, Editora da Universidade Estadual de Londrina, p. 347-400.

Oliveira, L.D.D., Souza-Cunha, F.L., and Locks, M., 1985, Um Hydrochoeridae (Mammalia, Rodentia) no Pleistoceno do nordeste o Brasil, in Campos, D.A., Ferreira, C.S., Brito, I.M., and Viana, C.F., eds., Coletânea de Trabalhos Paleontológicos, Brasília, Departamento Nacional da Produção Mineral, Série Geologia no. 27, p. 93-97.

Oliveira, P.V., 2010, Mamíferos do Neopleistoceno-Holoceno do Parque Nacional de Ubajara, Ceará [Masters thesis], Porto Alegre, Universidade Federal do Rio Grande do Sul, 167 p.

Patterson, B., and Wood, A.E., 1982, Rodents from the Deseadan Oligocene of Bolivia and the relationships of the Caviomorpha: Bulletin of the Museum of Comparative Zoology, v. 149, no. 7, p. 371-543.

Paula Couto, C., 1971, Mamíferos fósseis das cavernas de Minas Gerais: Espeleologia, v. 3-4, p. 3-14.

Paula Couto, C., 1978, Mamíferos fósseis do Pleistoceno do Espírito Santo: Anais da Academia Brasileira de Ciências, v. 50, no. 3, p. $365-379$

Pessôa, L.M., Corrêa, M.M. de O., de Oliveira, J.A., and Lopes, M.O.G., 2004, Karyological and morphometric variation in the genus Thrichomys (Rodentia: Echimyidae): Mammalian Biology, v. 69, p. 258-269. doi:10.1078/1616-5047-00141.

Pérez, M.E., 2010, A new rodent (Cavioidea, Hystricognathi) from the middle Miocene of Patagonia, mandibular homologies, and the origin of the crown group Cavioidea sensu strict: Journal of Vertebrate Paleontology, v. 30, no. 6, p. 1848-1859. doi:10.1080/02724634.2010.522432.

Poux, C., Chevret, P., Huchon, D., De Jong, W.W., and Douzery, E.J.P., 2006, Arrival and diversification of caviomorph rodents and plathyrrine primates in South America: Systematic Biology, v. 55, v. 2, p. 228-244. doi:10.1080/10635150500481390.

Quadros, M.L.E.S., 1996, Estudo tectono-sedimentar da Bacia de Jaibaras, na região entre as cidades de Pacujá e Jaibaras, noroesta do Estado do Ceará. [Masters thesis]: Belém, Universidade Federal do Pará, $134 \mathrm{p}$.

Quintana, C.A., 1996, Diversidad del roedor Microcavia (Caviomorpha, Caviidae) em América del Sur: Mastozoología Neotropical, v. 3, no. 1 , p. $63-86$.

Reis, S.F., and Pessôa, L.M., 2004, Thrichomys apereoides: Mammalian Species, no. 741, p. 1-5. doi:10.1644/741.

Rodrigues, P.H., Santos, J.D.F., and Silva, A.K.B., 2011, Assembleia holocênica de vertebrados de pequeno porte do Sítio Alcobaça, Estado de Pernambuco, Brasil, in Anais, Congresso Brasileiro de Paleontologia, $22^{\text {th }}$, Natal, p. 636-638.

Rowe, D.L., and Honeycutt, R.L., 2002, Phylogenetic relationships, ecological correlates, and molecular evolution within the Cavioidea (Mammalia, Rodentia): Molecular Biology and Evolution, v. 19, p. 263-277.

Salles, L.O., Cartelle, C., Guedes, P.G., Boggiani, P.C., Janoo, A., and Russo, C.A.M., 2006, Quaternary mammals from Serra da Bonoquena,
Mato Grosso do Sul, Brazil, Boletim do Museu Nacional, Nova Série Zoologia, no. 521, 12 p.

Salles, L.O., Carvalho, G.S., Weksler, M., Sicuro, F.L., Abreu, F., Camardella, A.R., Guedes, P.G., Avilla, L.S., Abrantes, E.A.P., Sahate, V., and Costa, I.S.A., 1999, Fauna de mamíferos do Quaternário de Serra da Mesa (Goiás, Brasil), Publicações Avulsas do Museu Nacional, no. 78, 15 p.

Toledo, P.M., Moraes-Santos, H.M., and Souza de Melo, C.C., 1999, Levantamento preliminar de mamíferos não-voadores da Serra dos Carajás: grupos silvestres recentes e zooarqueológicos: Boletim do Museu Paraense Emílio Goeldi, v. 15, no. 2, p. 141-157.

Trajano, E., and Ferrarezzi, H., 1994, A fossil bear from northeastern Brazil, with a phylogenetic analysis of the South American extinct Tremarctinae (Ursidae): Journal of Vertebrate Paleontology, v. 14, no. 4, p. 552-561. doi:10.1080/02724634.1995.10011577.

Ubilla, M., Oliveira, E.V., Rinderknecht, A., and Pereira, J., 2008, The hystricognath rodent Microcavia in the Late Pleistocene of Brazil (Rio Grande do Sul, South America) (Mammalia: Caviidae). Biogeographic and paleoenviromental implications: Neues Jahrbuch für Geologie und Paläontologie, Abhandlungen, v. 247, no. 1, p. 15-21. doi:10. 1127/0077-7749/2008/0247-0015.

Verzi, D.H., Vucetich, M.G., and Montalvo, C.I., 1995, Un nuevo Eumysopinae (Rodentia, Echimyidae) del Mioceno tardio de la provincia de La Pampa y consideraciones sobre la historia de la subfamilia: Ameghiniana, v. 32, no. 2, p. 191-195.

Vucetich, M.G., and Ribeiro, A.M., 2003, A new and primitive rodent from the Tremembé Formation (Late Oligocene) of Brazil, with comments on the morphology of the lower premolars of caviomorph rodents: Revista Brasileira de Paleontologia, v. 5, p. 73-82.

Vucetich, M.G., Souza Cunha, F.L. de, and Alvarenga, H.M.F., 1993, Un roedor Caviomorpha de la Formación Tremembé (Cuenca de Taubaté), Estado de São Paulo, Brasil: Anais da Academia Brasileira de Ciências, v. 65, p. 247-251.

Vucetich, M.G., and Verzi, D.H., 1994, Las homologías en los diseños oclusales de los roedores Caviomorpha: un modelo alternativo: Mastozoología Neotropical, v. 1, p. 61-72.

Vucetich, M.G., and Verzi, D.H., 2002, First record of Dasyproctidae (Rodentia) in the Pleistocene of Argentina. Paleoclimatic implication: Palaeogeography, Palaeoclimatology, Palaeoecology, v. 178, p. 67-73. doi:10.1016/S0031-0182(01)00402-3.

Vucetich, M.G., Verzi, D.H., and Tonni, E.P., 1997, Paleoclimatic implications of the presence of Clyomys (Rodentia, Echimyidae) in the Pleistocene of central Argentina: Palaeogeography, Palaeoclimatology, Palaeoecology, v. 128 , p. 207-214. doi:10.1016/S00310182(96)00050-8.

Woods, C.A., and Howland, E.B., 1979, Adaptive radiation of capromyid rodents: anatomy of the masticatory apparatus: Journal of Mammalogy, v. 60 , p. $95-116$.

Woods, C.A., and Kilpatrick, C.W., 2005, Infraorder Hystricognathi, in Wilson, D.E., and Reeder, D.M., eds., Mammal Species of the World: A Taxonomic and Geographic Reference, 3rd ed., Baltimore, Johns Hopkins University Press, p. 1538-1600.

Wyss, A.R., Flynn, J.J., Norell, M.A., Swisher, III., C.C., Charrier, R., Novacek, M.J., and McKenna, M.C., 1993, South America's earliest rodent and recognition of a new interval of mammalian evolution: Nature, v. 365, p. 434-437. doi:10.1038/365434a0.

APPENDIX 1-Comparative specimens: Thrichomys apereoides: MN63199, MN-63198, MN-63701, MN-63217, MN-63200, MN-63202, MN63215, MN-63202, MN-63226, MN-63205, MN-63206, MN-63210, MN63228, MN-63216, MN-63295, MN-66059. T. inermis: MN-140 (79-91), MN-14098, MN-14 (100-101). T. pachyurus: MN-64029 - 30, MN-64112, MN-64127, MN-64060, MN-64132, MN-64062, MN- MN-64243, MN64062, MN-64065, MN-64067. Kerodon rupestris: MN-263 (41-44), MN263 (45-55), MN-26708, MN-2670 (00-04), MN-267 (10-14). K. acrobata: MN-22729 (holotype), MN- 22728, MN-22730. Galea spixii: MN-2607, MN-2031. Microcavia australis: MLP-683 (1-10), Cavia aperea: MCPU-M 007, MCPU-M 034. Dasyprocta azarae: MN-30477, MN-30468, MN43172, MN-43175, MN-43169, MN-43173, MN-34387, MN-2292, MN2296, MN-64487, MN-4857. D. prymnolopha: MN-43216, MN-1496, MN43149, MN-43145, MN-43156, MN-43154, MN-43153, MN-10244, MN7637, MN-43152, MN-7636. Myoprocta exilis: MN-268 (92-93), MN- 268 (96-97), MN-26899, MN-269 (00-05). 